\section{Antibody titres to campylobacter pylori after treatment for gastritis}

\author{
D Vaira, J Holton, S R Cairns, $M$ Falzon, \\ A Polydorou, J F Dowsett, P R Salmon
}

\begin{abstract}
Middlesex Hospital, London W1N 8AA

$\mathrm{D}$ Vaira, $\mathrm{MD}$, research assistant in gastroenterology

J Holton, MRCPATH, senior lecturer in microbiology

S R Cairns, MRCP, senior registrar in gastroenterology M Falzon, MRCPATH, senior registrar in histopathology A Polydorou, clinical assistant, gastroenterology J W Dowsett, FRACP, research fellow in gastroenterology P R Salmon, FRCP, consultant gastroenterologist
\end{abstract}

Correspondence to: Dr Dino Vaira. antibody to $C$ pylori before and after treatment.

\section{Patients, methods, and results}

Campylobacter pylori is strongly associated with histologically confirmed gastritis. ${ }^{12}$ The most convincing evidence for a pathogenic role of $C$ pylori in gastritis comes from trials of treatment. ${ }^{3+}$ We investigated the role of $C$ pylori in dyspeptic patients who had gastritis confirmed by histology by performing a prospective trial with colloidal bismuth subcitrate $240 \mathrm{mg}$ twice daily for four weeks. We also report the titres of

We studied 66 patients who had dyspepsia without ulcers and took three endoscopic biopsy specimens from both the gastric antrum and duodenal bulb. One specimen was placed in $10 \%$ buffered formalin for histology (colonising $C$ pylori were identified by Giemsa stain), and the second was put in $6 \%$ urea solution $\left(C\right.$ pylori test). ${ }^{5}$ The third was placed in $0.5 \mathrm{ml} \mathrm{20 \%}$ sterile glucose, homogenised, treated with Gram stain, cultured on blood agar with amphotericin $(6 \mu \mathrm{g} / \mathrm{ml})$ and incubated at $37^{\circ} \mathrm{C}$ for six days. Patients who had a positive $C$ pylori test result from the antrum started receiving treatment the same day as endoscopy. Blood was taken before and after treatment for antibody assessment by ELISA (enzyme linked immunosorbent assay) (sonicated antigen was used and titres determined at optical density $470 \mathrm{~nm}$ ). Statistical analysis was by two tailed Mann-Whitney $U$ test and matched paired $t$ test after log transformation.

Antral histology showed acute or chronic gastritis, or both, in 32 patients, all of whom showed $C$ pylori on microscopy. The 34 patients who had normal mucosal histology did not have $C$ pylori and did not receive treatment. At the time of the second endoscopy (one week after finishing treatment) blood was taken, and careful questioning showed that only 19 of 31 patients had complied fully with the four week course of colloidal bismuth subcitrate, despite patients' and doctors' initial consent to participate in the study. Five patients received colloidal bismuth subcitrate for two weeks only, six ranitidine $300 \mathrm{mg}$ daily for four weeks, and one metronidazole $200 \mathrm{mg}$ every eight hours for two weeks. One patient was lost to follow up because he went overseas.

In 13 of 19 patients treated with colloidal bismuth subcitrate histology showed that gastritis had completely resolved and microscopy showed no $C$ pylori. In six patients there was considerable improvement in the histological samples as well as a decrease in the amount of bacteria. Five patients who took colloidal bismuth subcitrate for only two weeks showed incomplete clearance of bacteria and gastritis. Histological samples from seven patients given ranitidine or metronidazole showed no change (four patients), mild improvement (one), or worsening (two).

Significantly higher IgG and IgA titres were found in patients who were positive for $C$ pylori than in patients who were negative for $C$ pylori $(\mathrm{p}<0.001$; MannWhitney $\mathrm{U}$ test). IgG and IgA antibody titres were significantly decreased after colloidal bismuth subcitrate treatment $(\mathrm{IgG}=$ estimated change of ratios $1 \cdot 21$, confidence interval $(\mathrm{CI}) 1 \cdot 10$ to $1 \cdot 32, \mathrm{t}=4 \cdot 31$, $\mathrm{p}<0.001$; IgA: estimated change $1 \cdot 58, \mathrm{CI} 1 \cdot 33$ to $1 \cdot 86$, $\mathrm{t}=5.57, \mathrm{p}<0.001)$ whereas those in patients given ranitidine or metronidazole showed no significant difference (IgG: estimated change $1 \cdot 02$, CI 0.91 to $1 \cdot 14, \mathrm{t}=0 \cdot 35, \mathrm{p}>0 \cdot 1 ; \operatorname{IgA}$ : estimated change $0 \cdot 98, \mathrm{CI}$ 0.81 to $1 \cdot 17, t=0 \cdot 33, p>0 \cdot 1)$. Indeed, some were even increased after treatment (figure). IgM titres were unchanged.

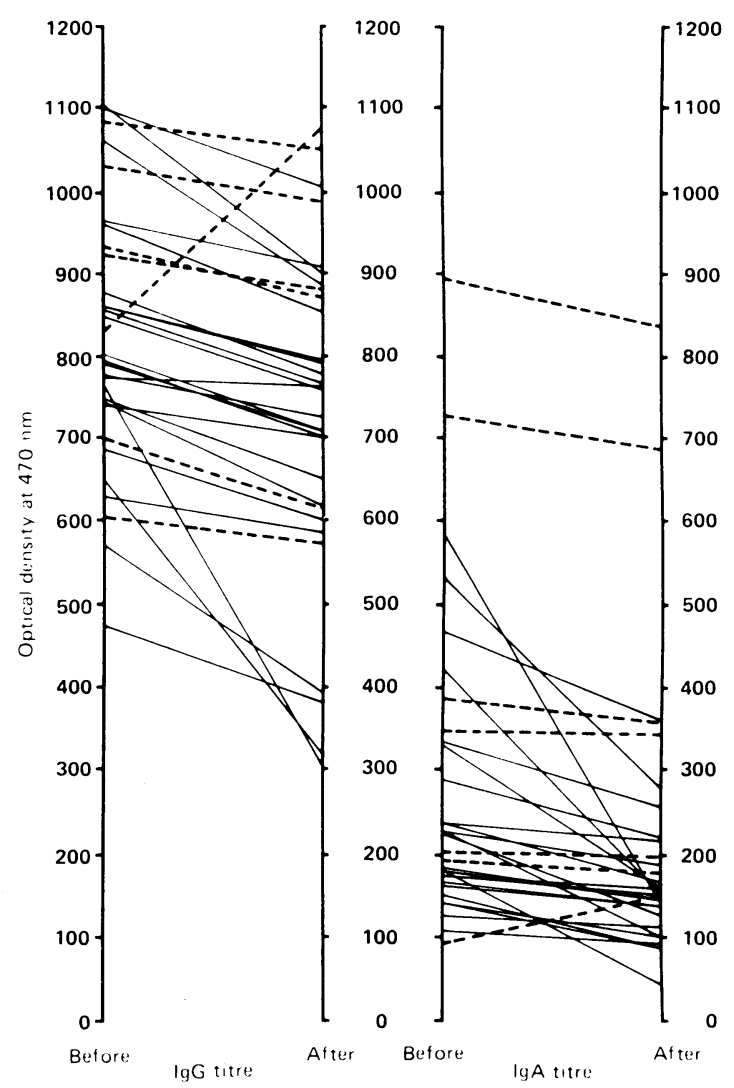

Serum IgG and IgA titres before and after treatment. $-=$ Colloidal bismuth subcitrate $(p<0 \cdot 001) .---=$ Ramitidine and metronidazole (NS)

\section{Comment}

To our knowledge this is the first report of antibody titres before and after treatment. IgG and IgA antibody titres to $C$ pylori may be useful in screening dyspeptic patients before endoscopy. The success of colloidal bismuth subcitrate and the inefficacy of H2-receptor antagonists in improving the histological features of gastritis as well as the number of $C$ pylori is also confirmed. Increased titres of IgG and IgA to $C$ pylori also provide evidence of active infection and may therefore be useful in following the response to treatment, compliance, and possibly reinfection.

We thank Mr J Osborn for the statistical analysis and $\mathrm{Mr}$ Neil Raymond for his help.

Vaira D, Holton J, Cairns SR, Falzon M, Salmon PR. Four hour rapid urease test (RUT) for the detection of Campylobacter pylori (CP): is it reliable enough to start therapv? I Clin Pathol 1988:41:355-6.

2 Rathbone BJ, Wyvatt JI, Worsley BW, et al. Systemic and local antibody responses to gastric Campylobacter pyloridis in non-ulcer dyspepsia. (iut 1986:27:642-7.

3 McNulty CAM, Gearty JC, Crump B, et al. Campylobacter pyloridis and associated gastritis: investigator blind, placebo controlled trial of bismuth salicylate and ervthromycin ethylsuccinate. Br Med f 1986;293:645-9.

4 Langenberg ML, Rauws EAJ, Schipper MEI, et al. The pathogenetic role of Campylobacter pyloridis by attempts to eliminate these organisms. In: Paerson AD, Skirrow MB, Lior H, Rowe B, eds. Campylobacter III: proceedings of the third international workshop on campvlobacter infection, Ottawa, 1985. London: Public Health Laboratory Service, 1985:162-3.

5 Vaira D, Holton J, Cairns S, Falzon M, Polydorou A, Salmon PR. Urease tests for Campylobacter pylori (CP): care in interpretation. 7 Clin Pathol 1988;41 $812-3$.

(Accepted 6 April 1988) 